\title{
ANALYSIS OF ENERGY SYSTEM IN NORWAY WITH FOCUS ON ENERGY CONSUMPTION PREDICTION
}

\author{
Maryam, HAMLEHDAR ${ }^{1}$ and Alireza, ASLANI ${ }^{1,2}$ \\ ${ }^{1}$ Renewable Energy Department, Faculty of New Sciences and Technologies, University of Tehran, Iran \\ ${ }^{2}$ Production Department, Faculty of Technology, University of Vaasa, Finland
}

\begin{abstract}
Today, the fossil fuels have dominant share of energy supply in order to respond to the high energy demand in the world. Norway is one of the countries with rich sources of fossil fuels and renewable energy sources. The current work is to investigate on the status of energy demand in Norway. First, energy and electricity consumption in various sectors, including industrial, residential are calculated. Then, energy demand in Norway is forecasted by using available tools. After that, the relationship between energy consumption in Norway with Basic economics parameters such as GDP, population and industry growth rate has determined by using linear regression model. Finally, the regression result shows a low correlation between variables.
\end{abstract}

KEY WORDS: Energy System, Energy modelling, Norway

\section{INTRODUCTION}

The global population continues to grow, and different countries develop rapidly. This fact causes an extensive increase in the energy demand, so providing this need has become a critical issue [1]. Considering the increasing rate of global energy consumption, energy demand is expected to increase about $65 \%$ by 2030 [2]. Because of limitations and environmental effects of fossil fuels, governments have implemented different strategies to reduce energy import dependency [3].

As an example, energy consumption is increasing highly in the Nordic countries (Denmark, Finland, Norway, Sweden and Island). These countries have tried to supply their energy need by utilization of more efficient and sustainable systems, as well as more affordable energy sources. This fact not only supplies energy demand, but also facilitate the transition to an environmentally sustainable society. Since the oil crisis in the early 1970s, Nordic countries have invested a lot to find alternative energy sources. As a result, replacing sources reduced the oil share from $70 \%$ in 1970 to $20 \%$ in 2012 [4].

In order to improve energy supply systems, different strategies have introduced as useful solutions. Two most efficient tools that can be used to improve existing and future energy systems are modeling and forecasting energy consumption. After that can conduct measures to achieve the goals Predicted of energy consumption and reduce dependence.

In this paper, the status of energy demand is investigated in one of the European countries, Norway. First, energy and electricity consumption are determined in different sectors, including industrial, residential, and etc. Then, energy demand in Norway is predicted by using available tools. After that, the relationship between energy consumption in Norway with
Basic economic parameters such as GDP, population and industry growth rate has determined using linear regression model. Finally, considering results extracted in the previous part, energy policy investigates in this country.

\section{LITERATURE REVIEW}

\subsection{Country situation}

Norway is one of the Nordic countries located in Northern Europe and West Nordic Peninsula. This country has a cool and mountainous climate. According to 2016 statistics, Norway has 5.22 million people and growth rate of $0.2 \%$ (www.norway statistic.com, 2012).

Norway is one of the most significant energy producer and exporters among Europeans. This country is one of the largest oil and gas exporter in the world. Also, it has the secondlargest reserves of natural gas in Europe, after Russia. (Miika Tommila, 2010).

In 2011, Norway produced 2311 TWh energy. In this statistic, crude oil, and natural gas were the largest parts with more than $90 \%$. Norway is rich with both of petroleum and RE sources. Every year 120135 TWh of RE is produced in this country. There is great potential for hydroelectric power and a large share of electricity is generated by this source. In the last decade, the share of produced electricity from RE that mainly is considered hydropower has accounted between 95 and 99 (Anne Therese Gullberg, 2014).

As of 1 January 2014, the total installed capacity in Norwegian hydropower plants was $30960 \mathrm{MW}$, split between 1476 power plants. The ten largest hydropower plants together account for nearly one fifth of the production capacity. Table 1 shows the numbers and installed capacity of hydropower plants in various size categories as of 1 January 2014 (Kjersti Aarrestad, 2014). 5 
Table 1. Operational hydropower stations by size and mean annual production. As of 01.01.2014. (www.nve.com)

\begin{tabular}{cccc}
\hline MW & Number & $\begin{array}{c}\text { Performance } \\
\text { (MW) }\end{array}$ & $\begin{array}{c}\text { Mean annual } \\
\text { production } \\
\text { (GWh/year) }\end{array}$ \\
\hline$<1 \mathrm{MW}$ & 554 & 175 & 0.8 \\
$1-10 \mathrm{MW}$ & 587 & 1989 & 8.3 \\
$10-100 \mathrm{MW}$ & 255 & 9523 & 43 \\
Over 100 & 80 & 19273 & 79.5 \\
Total & 1476 & 30960 & 132 \\
\hline
\end{tabular}

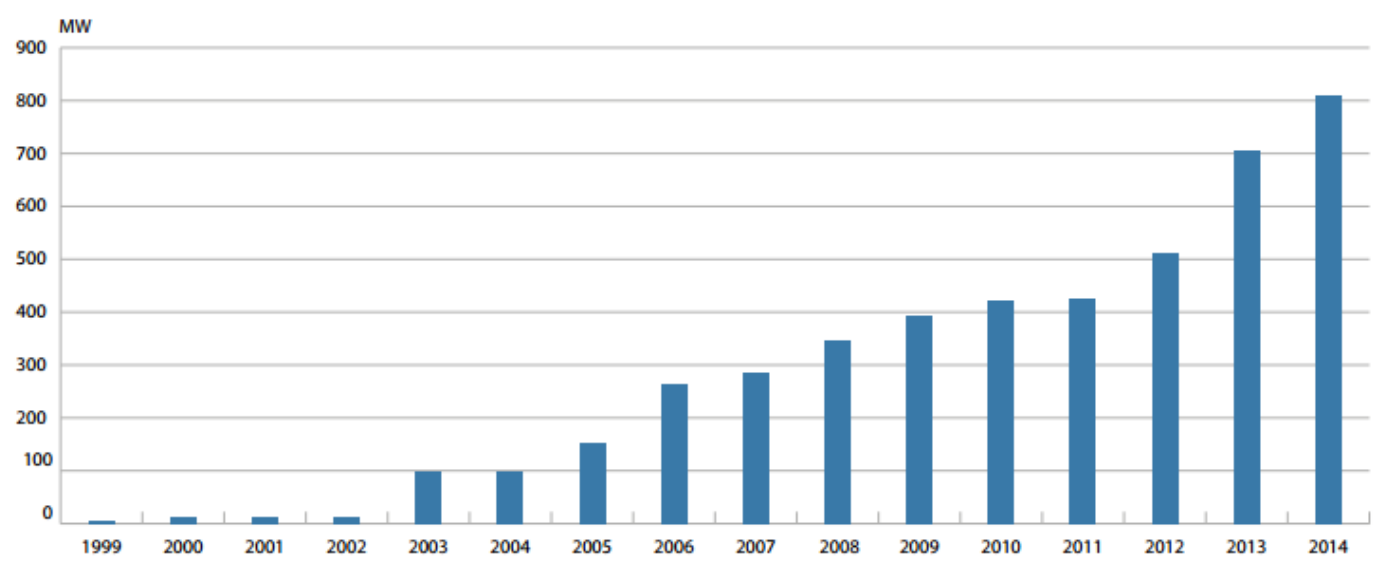

Figure 1. Installed peak wind power capacity. 1999 to 2014. (www.norway statistic.com, 2012)

According to the organization for Economic Co-operation and Development (OECD) statistics, Norway is one of the richest countries in the world. In fact, it has the second place among OECD countries in terms of GDP per capita (after Luxembourg). One of the main reasons is that the petroleum sector is the spine of the Norwegian economy. For instance in 2009 , this sector produced $22 \%$ of GDP, $47 \%$ of exports, and also $27 \%$ of this its government revenue (Miika Tommila, 2010). Nevertheless there is no fossil fuel dependency on imports in any sector of this country.
Norway generally has good wind resources, compared with other countries. The average annual wind speed 50 metres above ground in an exposed coastal area in Norway can be 7-9 $\mathrm{m} / \mathrm{s}$. At the start of 2014, Norway had $811 \mathrm{MW}$ of installed wind power, provided by 356 turbines in 20 registered wind farms, see Figure 1 (Kjersti Aarrestad, 2014).

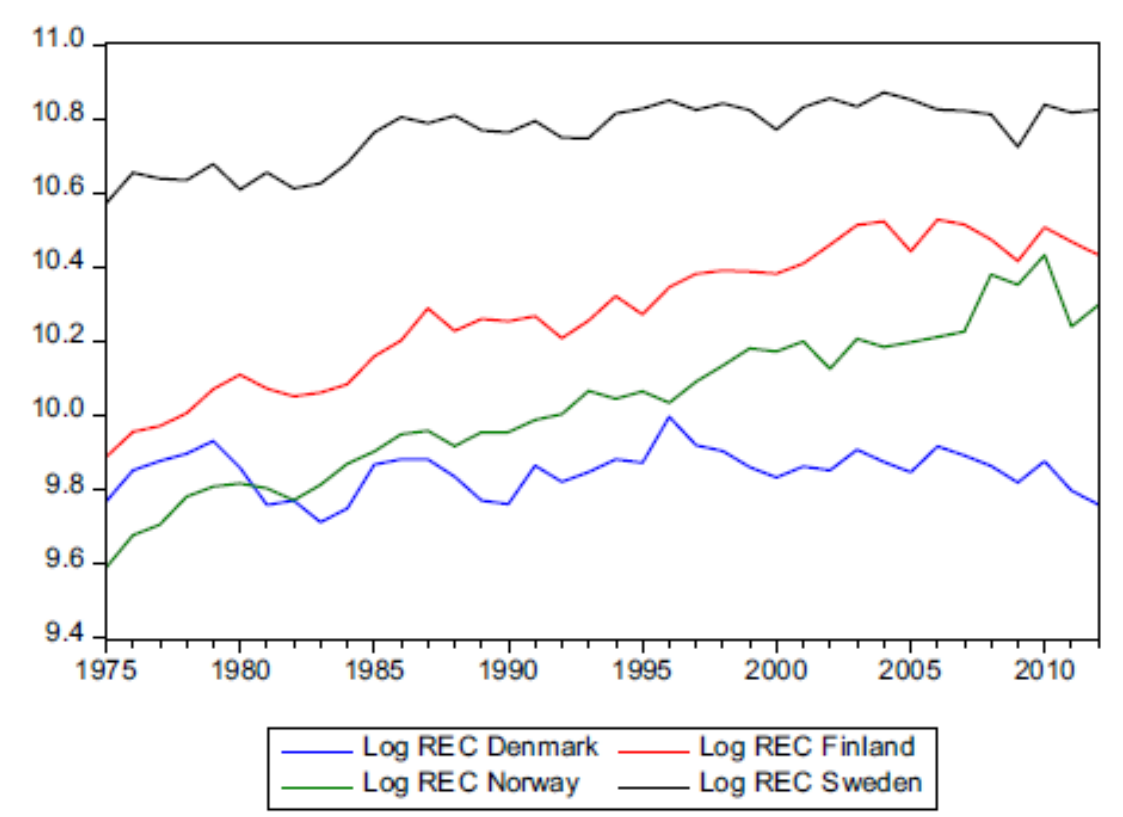

Figure 2. RE consumption in the Nordic countries (1975-2012) (Irandoust, 2016)

The international energy agency (IEA) encouraged Norway to utilize its high hydropower capacity, to balance differences in demand and supply, as the largest in Europe after Russia. More hydropower resources, not only enhance flexibility in the
Nordic countries consume more energy, their carbon dioxide emissions is compared with the EU average of 8 tons and the US average of 19 tons are 5 tons per year. The reason for this is that most part of electricity in these countries supplied by nuclear and hydroelectric power plants, cogeneration from combined heat and power, and the wind turbines (Irandoust, 2016). Fig 2 shows time plot of RE generation in terms of thousand tons in the Nordic countries from 1975 to 2012. electricity market integration in Europe but also puts Norway in a favorable strategic position (Miika Tommila, 2010).

\subsection{Energy balance analysis}

According to Sankey curve, in 2013 total primary energy 6 
supply (TPES) in Norway was 32706 ktoe, 4.8\% biomass, $0.7 \%$ geothermal, the wind and, solar, $33.3 \%$ hydropower, $17.3 \%$ natural gas, $41.5 \%$ crude oil and $2.3 \%$ coal (www.iea.org). As it is illustrated in figure 3, crude oil, hydropower and natural gas were the largest energy supplies in Norwey.

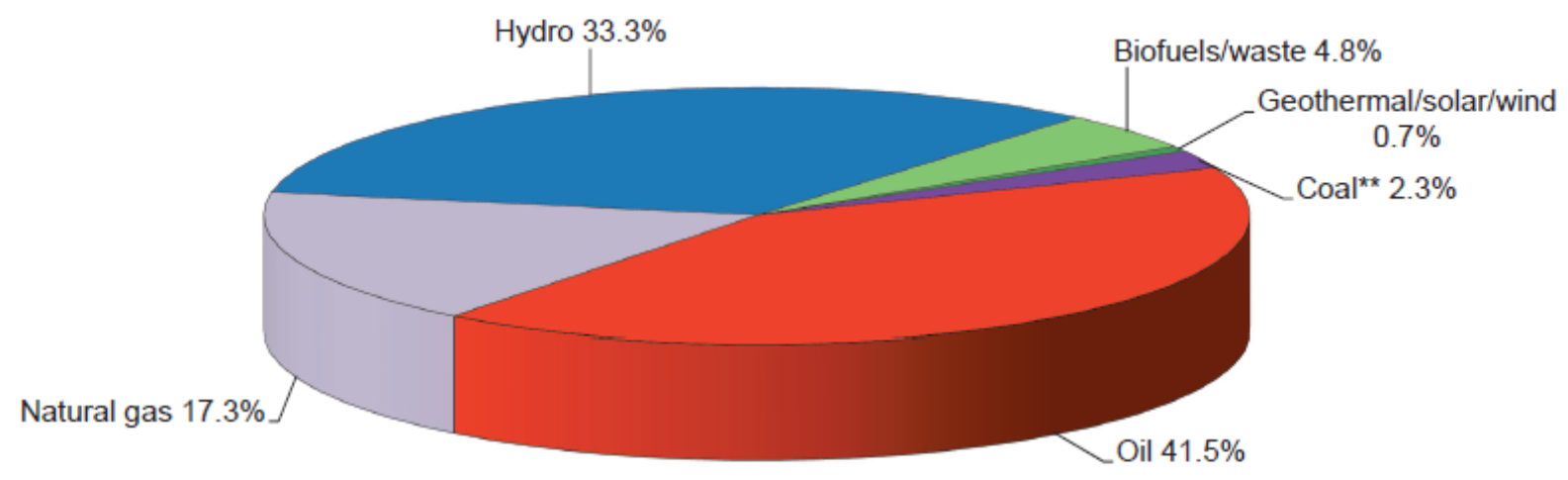

Figure 3. The share of TPES in 2013 (www.iea.org)

The results indicated trend of TPES has increased from 1971 to 2013 for all sources, but it was decreased in 2010 and 2011 because of the world recession. According to figure 4 as a renewable resource between all energy reserves, hydropower has increased much higher. It shows the great potential of Norway to use this renewable resource.

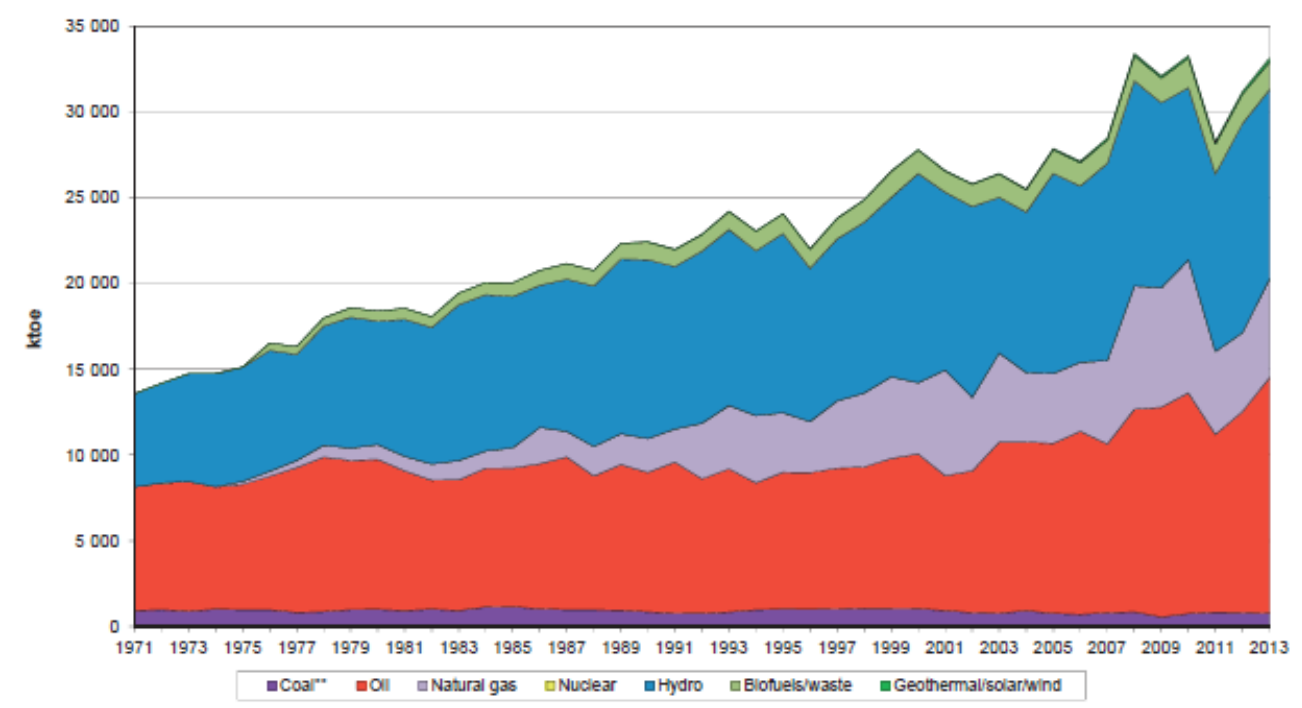

Figure 4. TPES in Norway (www.iea.org).

According to the Norwegian energy balance statistics, the maximum part of energy production is related to crude oil, natural gas, and hydropower, respectively. The most part of the crude oil and natural gas production is exported and only a small amount of it is stored. That's why oil production owns the biggest share of imports. Although the biggest share of natural gas and crude oil are exported every year, in recent years the total export has a downward trend. For instance, in 2013 their export was reduced by $7 \%$ over the previous year. Energy resource production trends are shown in figure 5 . The hydropower production has enhanced, however, it declined for crude oil as a fossil fuel (www.iea.org). 


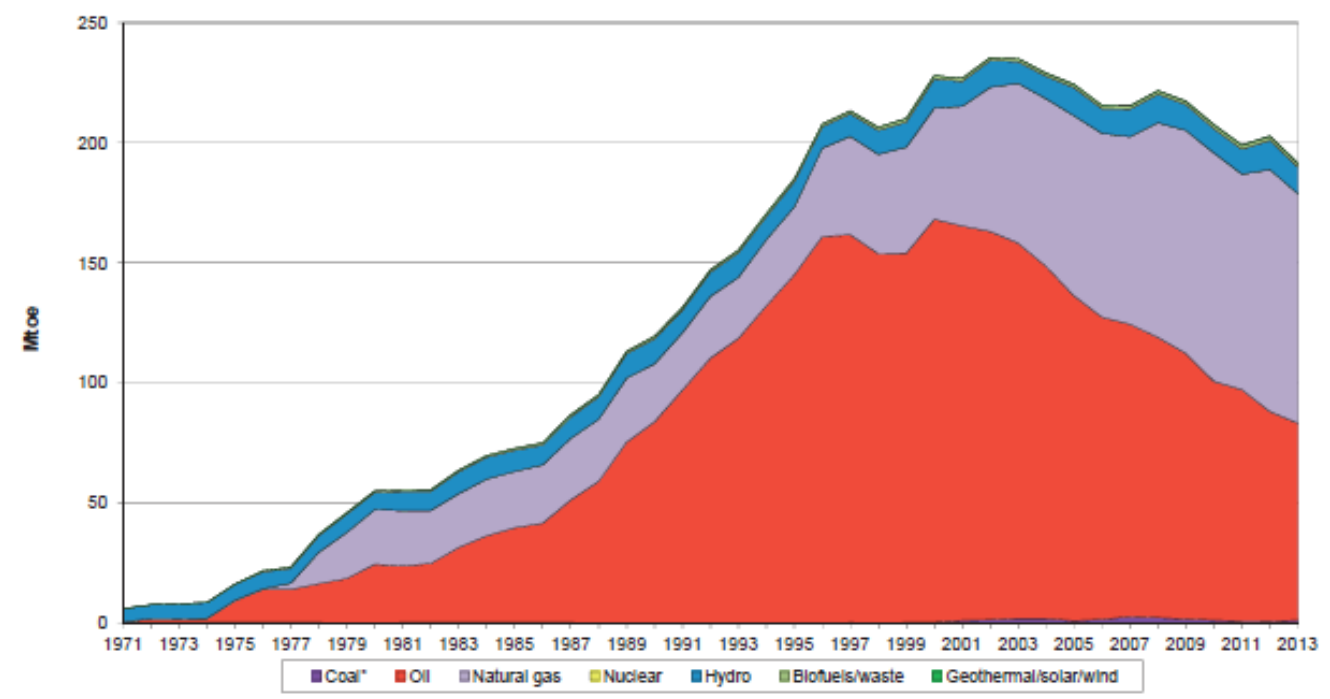

Figure 5. Energy production in Norway (www.iea.org).

Based on the Norway energy balance reported by IEA, in 2013 the total final consumption was 20435 Ktoe. Which decreased $0.16 \%$ over the previous year. The share of production electricity and production oil in total final consumption were $46 \%$ and $40 \%$, respectively. In the year the industrial sector with 5785 Ktoe and $28 \%$, the transport sector 4780 Ktoe and $23.39 \%$ and the household sector with 3938 Ktoe and $19.2 \%$ had the highest rate of energy demand (www.iea.org).

\subsection{Energy demand in the residential sector}

In 2013 electricity had very high amount 3187 Ktoe and $80 \%$ and after that respectively biomass, oil products, heat and

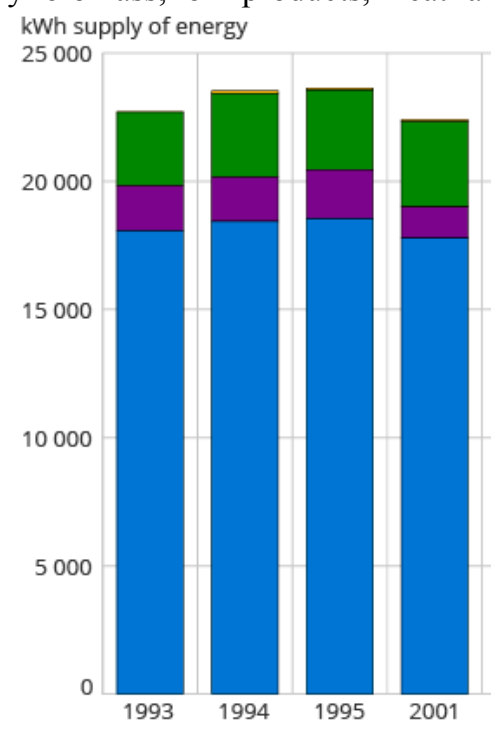

natural gas had the most demand in the residential sector. As the share of natural gas was 4 Ktoe, and it had only $0.1 \%$ of energy consumed in the residential sector. Recently, energy consumption has decreased in this sector because of high efficiency in the country's energy system. Fig 6 shows energy consumption, by Norwegian households. The statistics show energy used in the residential sector in 2013 declined by $5 \%$ compared with last year that. It is recognizable that oil product and natural gas consumption in this sector has a decreasing trend (www.iea.org).

Figure 6. Energy consumption, by household (www.norway statistic.com, 2012).

Energy consumption per household has had a declining trend since 1990s, both in total per household. Energy consumption in the household sector is compared in 2009 with 2012 in the figure 7 . The Result shows that average energy consumption per household in 2012 was $20230 \mathrm{kWh}$, including approximately $16000 \mathrm{kWh}$ of electricity and $3200 \mathrm{kWh}$ of fuel wood. The oil consumption has dropped with $700 \mathrm{kWh}$ in this year so, this accounted half of the oil consumption level in 2006. Despite the fact that it was warmer in 2009 than in 2012, the average energy consumption in 2012 was lower than in 2009. (www.norway statistic.com, 2012).
In 2014 , the total domestic energy consumption excluding the industries and consumption of raw materials with 209 TWh decreased by $4 \%$ compared to the previous year. In this regard, energy consumption by households and services was 9 $\%$ lower than the year before, which is widely related to the high temperatures in 2014. Since a large proportion of the energy consumption in these groups is associated with heating, the high temperature in 2014 was the main reason for this decline. Almost $80 \%$ of the energy consumption in these groups is related to electricity, and the electricity consumption met $8 \%$ fall in 2014 (www.norway statistic.com, 2012). 


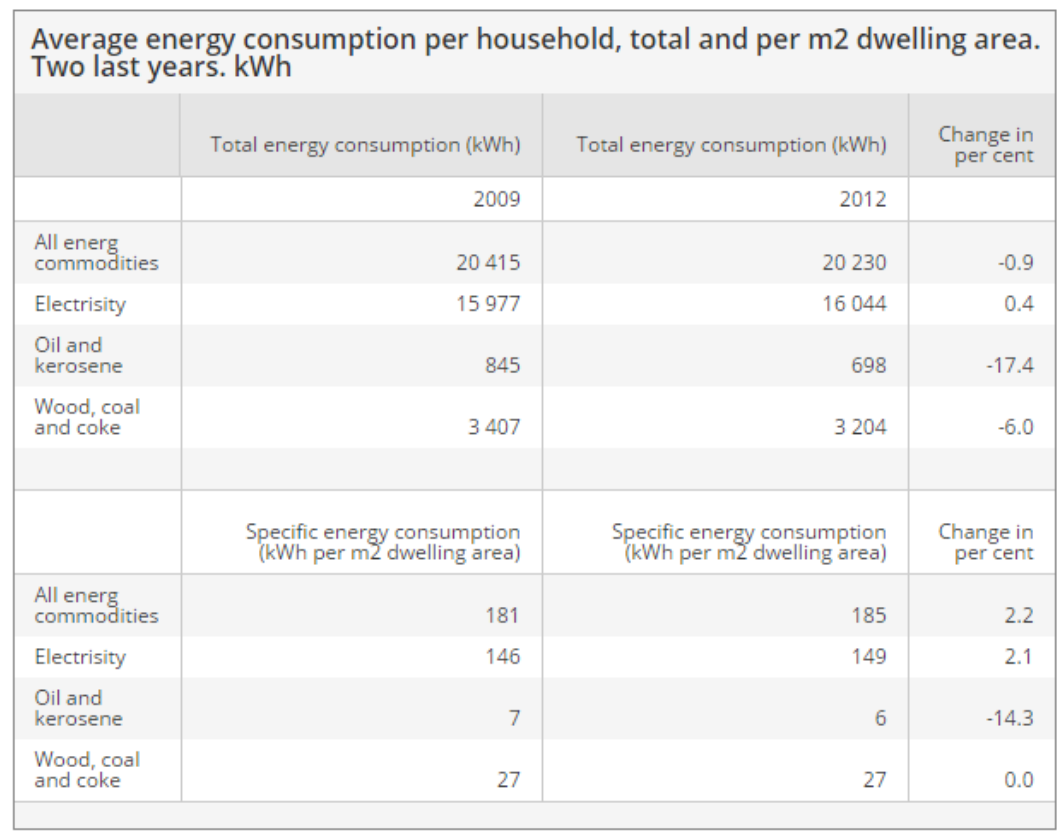

Figure 7. Total and per m2 average energy consumption of dwelling areas in 2009 and 2012 (www.norway statistic.com, 2012).

\subsection{Energy demand in the industrial sector}

In 2013, energy demand in the industrial sector was mostly related to the electricity with the amount of 3739 Ktoe $(64.5 \%)$. Other resources using in this sector were oil products, coal, biomass, natural gas and heat. Actually, one of the most important sources of energy, crude oil, is not consumed in this sector. Norway energy balance result shows total energy consumption had a rising trend in the industrial part. It has increased $0.3 \%$ compared to the previous year which made GDP improvement and Industrial growth rate (www.iea.org). Oil products and natural gas have declined respectively $7 \%$ and $3 \%$ in the manufacturing industries, while there was a rise about $5 \%$ in consumption of electricity in 2014 . Consumption in other energy-intensive manufacturing industries rose in 2014 by $4 \%$ compared to the previous year (www.norway statistic.com, 2012).

\subsection{Energy consumption comparison in residential and industrial sectors}

The household sector is faced with a slowly ascending trend however curve is almost linear and climb. However, energy consumption faced a sudden increase in 2010 because of high electricity demand, it came back to its normal trend again. Household consumption decrease in 2011 could be due to the global warming and lower heating needs (www.iea.org).

The industrial sector has shown more severe fluctuations than residential. Figure 8 illustrates that the lowest industrial consumption was in 2009. As discussed above, electricity use had the greatest impact on total energy consumption in this sector.

According to the graph trend of energy consumption is almost horizontal between 2010 and 2013 and energy consumption associated with recession.

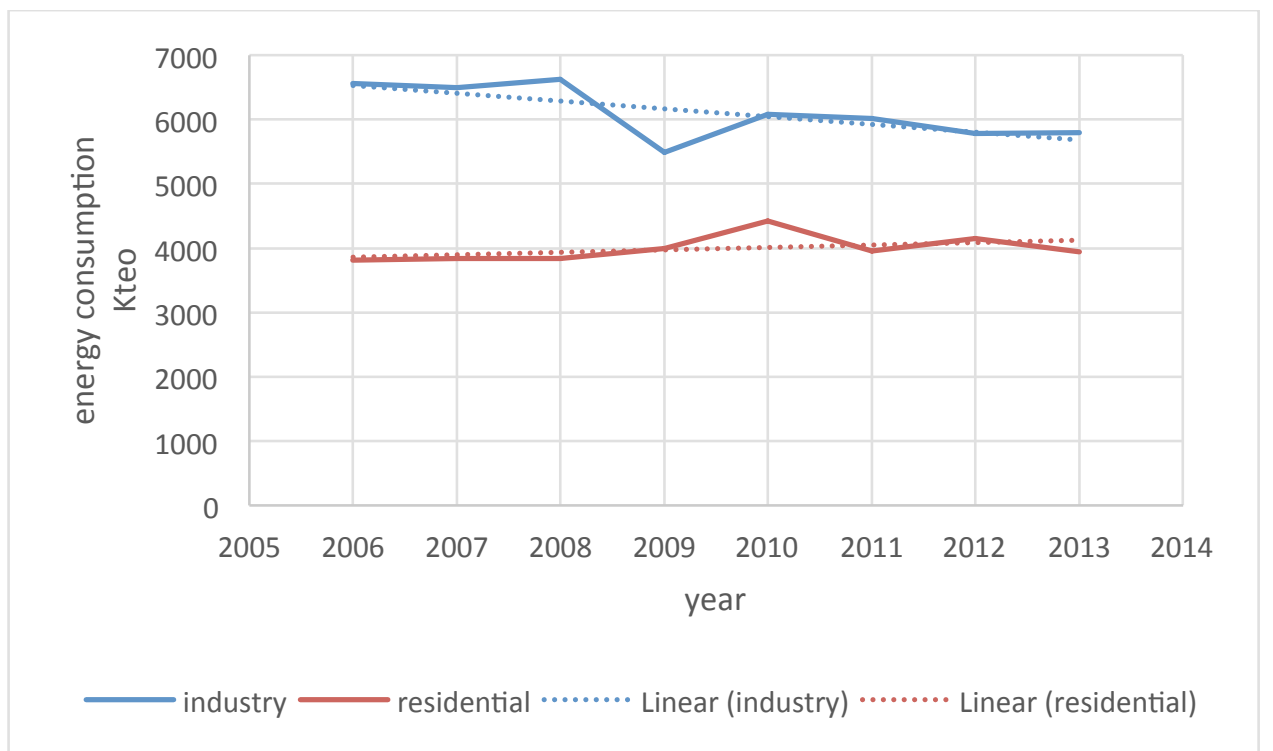

Figure 8. Energy consumption by industry and residential (www.iea.org).

\subsection{Energy demand in the transport sector}

Statistics in 2013 showed a demand for oil products with a value of 4489 Ktoe and $93.3 \%$ was the highest, while natural gas with 103 Ktoe and $2 \%$ had the lowest value in the transport sector. However oil products have increased in recent years, natural gas use have had a decreasing trend (www.iea.org).

In 2014 total energy consumption estimated around 65 GWh for transport purposes felt by $2 \%$ in comparison with the 9 
previous year. Nevertheless, Electricity consumption for electric vehicles had an increasing trend. The use of biofuels for transport purposes has improved in value around $1.5 \mathrm{TWh}$ in both 2013 and 2014. Total consumption of biofuels accounted for no more than $5 \%$ of net domestic energy consumption in this year, but is important for meeting the commitments in the RE Directive (www.norway statistic.com, 2012).

\subsection{Electricity}

As it is discussed before, this large and mountainous country supplies almost all of its electricity from hydropower resources. This fact strongly distinguishes Norway from other members of IEA. Two-thirds of production electricity is provided by RE sources in northern Europe, which one of this reason is the large capacity of hydropower in Norway (Irandoust, 2016).According to fig 9 hydropower resources have the largest proportion in generating electricity, during the past 40 years.

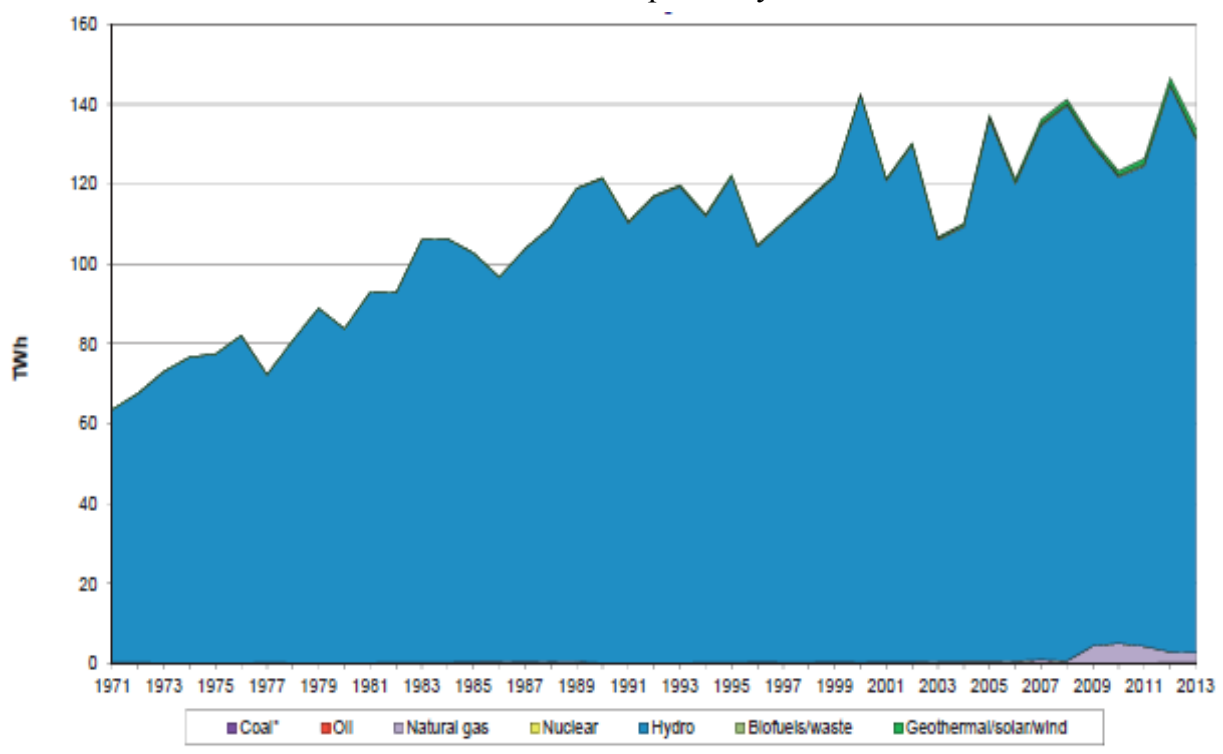

Figure 9. Electricity production by fuel (www.iea.org).

Figure 10 shows electricity use per capita in 2008. As it is illustrated in this figure, Norway was higher than other IEA members and it has the second place in the world. In this year, average use per capita was more than $23 \mathrm{MWh}$ in Norway, while the IEA and the world average were only 9 and 2.5 MWh, respectively. It shows the great electricity production in Norway and their ability to export the exceed production (Miika Tommila, 2010).

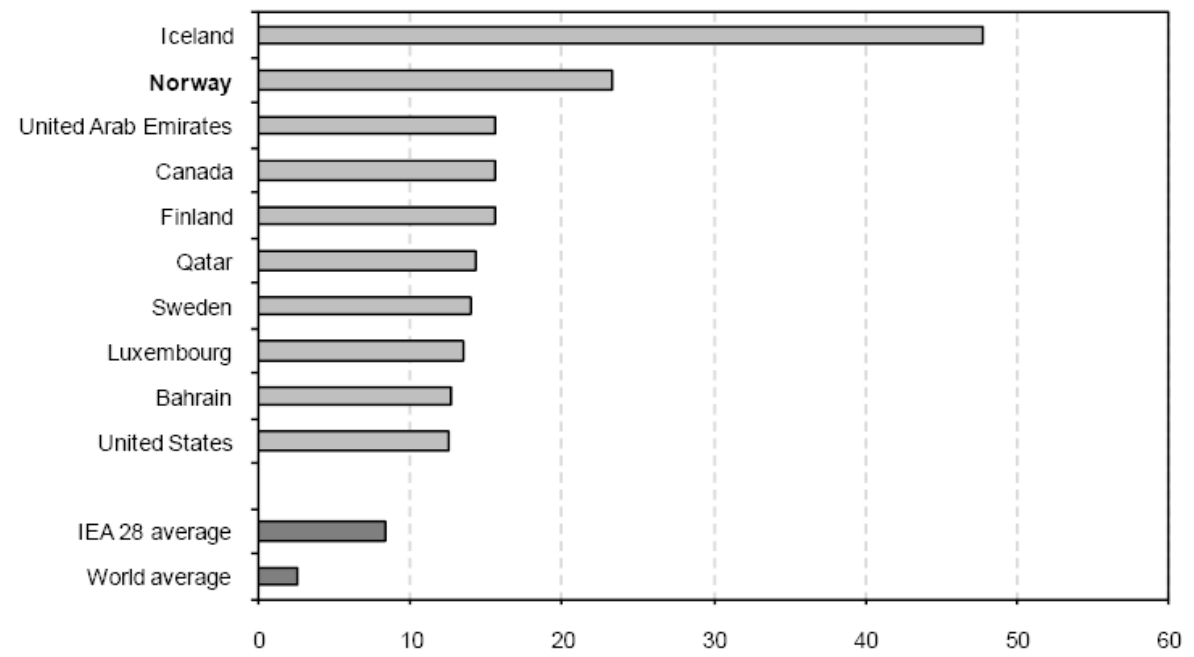

Figure 10. Electricity consumption per capita by countries, 2008 Sources (Energy Balances of OECD Countries, IEA/OECD Paris, 2010, and Energy Balances of non-OECD Countries, IEA/OECD Paris, 2010.C OECD/IEA, 2011).

Figure 11 shows the total final consumption of electricity in Norway in the last 10 years, Although, in these years, final consumption of electricity has had a lot of fluctuations, but it has been associated with a gentle upward trend. In 2013 total final electricity consumption was 9397 Ktoe (about $46 \%$ of total final consumption) and it has reduced $1.29 \%$ compared to 2012 (www.iea.org).
Indeed, electricity consumption ratio is very high, since this energy source often replaces oil and gas in deferent sectors like industry and residential (Miika Tommila, 2010). Also, Norway uses electricity in the heating of space and water to a much greater rate than the other Nordic countries, which have more developed district heating systems though underground water pipes (Irandoust, 2016). As a result, the supply of electricity in this country has a vital role. 


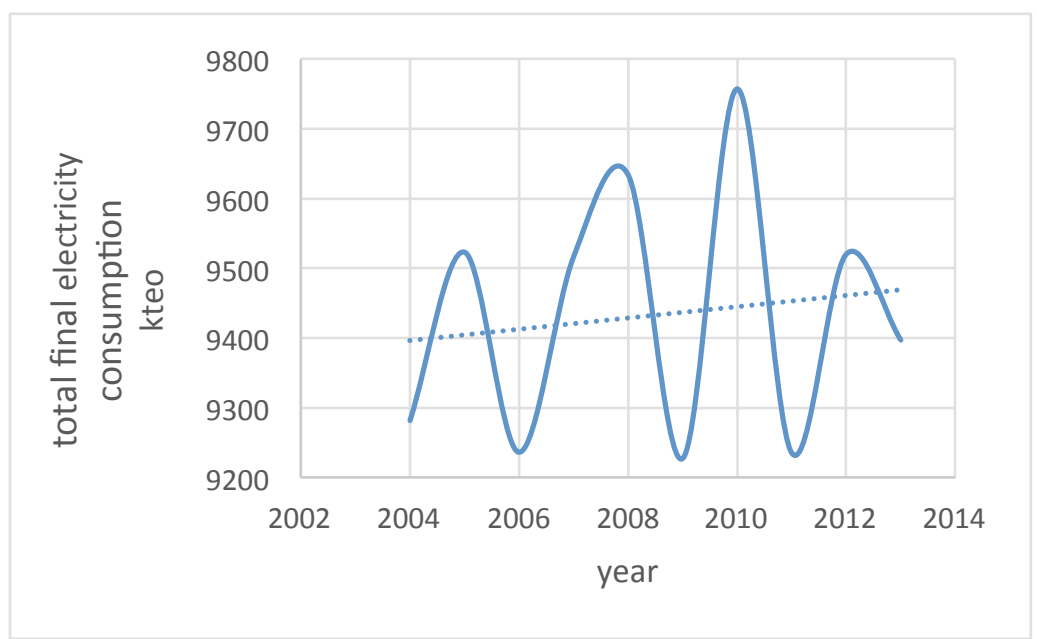

Figure 11. Total final electricity consumption (www.iea.org).

\subsection{Electricity price}

The average electricity price in the first quarter of 2016 for households and service industry excluding taxes and grid rent were respectively 28.7 and 27.3 NOK per $\mathrm{kWh}(\mathrm{NOK}=$ 0.108171 EUR). Therefore prices are $8.3 \%$ and $6.2 \%$ lower than the past year, respectively. In 2015 electricity consumption rose around $1 \%$, however, $4 \%$ declining in the electricity price contributed to NOK 400 million decrease in the total energy costs (www.norway statistic.com, 2012).

\section{DEMAND FORECASTING IN NORWAY}

In this section, energy consumption is forecasted by using prediction models including regression and trend line equation.

\subsection{Regression Model}

The relationship between a dependent variable with independent variables is expressed in the form of multivariate linear regression model or complex. In this part, energy consumption in 2014 is forecasted by using Regression Model thus total energy consumption in Norway in the last 10 years is consumed as the dependent variable and GDP, population and industrial growth rates are considered as independent variables to forecast energy consumption in 2014.Table 2 shows the extracted information to predict.

Table 2. GDP, population, and industrial growth rates (www.data.world-bank.org), (www.indexmundi.com).

\begin{tabular}{ccccc}
\hline year & total consumption & $\begin{array}{c}\text { GDP at market prices } \\
\text { (current US\$) Norway }\end{array}$ & Population & Industrial growth rate \\
\hline 2004 & 20488 & $2.64357 \mathrm{E}+11$ & 4591910 & 5.2 \\
2005 & 20453 & $3.08722 \mathrm{E}+11$ & 4623291 & -0.5 \\
2006 & 20406 & $3.45425 \mathrm{E}+11$ & 4660677 & 1.8 \\
2007 & 20872 & $4.00884 \mathrm{E}+11$ & 4709153 & 0.1 \\
2008 & 20963 & $4.61947 \mathrm{E}+11$ & 4768212 & -0.2 \\
2009 & 20031 & $3.86384 \mathrm{E}+11$ & 4828726 & -2.9 \\
2010 & 21351 & $4.28525 \mathrm{E}+11$ & 4889252 & 0.3 \\
2011 & 20426 & $4.98157 \mathrm{E}+11$ & 4953088 & -4.3 \\
2012 & 20468 & $5.09705 \mathrm{E}+11$ & 5018573 & 6.5 \\
2013 & 20435 & $5.22349 \mathrm{E}+11$ & 5079623 & -3 \\
\hline
\end{tabular}

Table 3. Information extracted from the regression

\begin{tabular}{|c|c|c|c|c|c|c|c|c|}
\hline \multicolumn{9}{|l|}{ SUMMARY OUTPUT } \\
\hline \multicolumn{9}{|c|}{ Regression Statistics } \\
\hline Multiple R & 0.940152883 & & & & & & & \\
\hline \begin{tabular}{|l|} 
R Square \\
\end{tabular} & 0.883887444 & & & & & & & \\
\hline Adjusted R Square & 0.825831166 & & & & & & & \\
\hline Standard Error & 372.9238368 & & & & & & & \\
\hline Observations & 10 & & & & & & & \\
\hline \multicolumn{9}{|l|}{ ANOVA } \\
\hline & $d f$ & $S S$ & $M S$ & $F$ & Significance $F$ & & & \\
\hline Regression & 3 & 6351982.872 & 2117328 & 15.2247 & 0.003271661 & & & \\
\hline Residual & 6 & 834433.1281 & 139072 & & & & & \\
\hline \multirow[t]{2}{*}{ Total } & 9 & 7186416 & & & & & & \\
\hline & Coefficients & Standard Error & $t$ Stat & P-value & Lower $95 \%$ & Upper 95\% & Lower $95.0 \%$ & Upper $95.0 \%$ \\
\hline Intercept & 48662.98936 & 13188.5965 & 3.68978 & 0.01021 & 16391.65629 & 80934.32242 & 16391.65629 & 80934.32242 \\
\hline GDP & $-2.02194 \mathrm{E}-10$ & $6.36057 \mathrm{E}-09$ & -0.03179 & 0.97567 & $-1.5766 \mathrm{E}-08$ & $1.53616 \mathrm{E}-08$ & $-1.5766 \mathrm{E}-08$ & $1.53616 \mathrm{E}-08$ \\
\hline population growth & -0.00431212 & 0.00268814 & -1.60413 & 0.15981 & -0.010889762 & 0.002265522 & -0.010889762 & 0.002265522 \\
\hline Industrial production growth & 105.2563298 & 19.21076538 & 5.47903 & 0.00154 & 58.2492803 & 152.2633793 & 58.2492803 & 152.2633793 \\
\hline
\end{tabular}

Table 3 shows information extracted from the regression. regarding this table, and calculated correlation coefficient, it is concluded that among total energy consumption in the last 10 years and GDP, population, and industry growth rate there is no correlation in Norway ( $\mathrm{R}$ Square $=0.19$ ). Due to this, 11 
below results can be extracted:

1. The effect of oil exports on Norway's GDP: As mentioned, oil exports as the backbone of Norway's economy has a significant impact on GDP growing.

2.The effect of downturn on energy consumption (2010 to 2011)

In 2011 industry growth rate fell because of the downturn in European countries whereby the energy consumption reduced.

3.The effect of efficiency energy system: (2011 to 2012) in 2012 , energy consumption is reduced under the influence the country's energy system efficiency.

Base on table 2 line equation has shown in equation (1):

$$
Y=-2.021 X_{1}-0.0043 X_{2}+105.25 X_{3}
$$

$\mathrm{X}_{1}$ : GDP

$\mathrm{X}_{2}$ : Papulation

$\mathrm{X}_{3}$ : Industrial growth rate

\subsection{Trend line equation}

Using derived trend line equation from the previous stage help to forecast three economic parameters GDP, population and industrial growth rate by 2020 . First, trend line equation of GDP calculated for the past 10 years by 2013, which is shown in equation (2). Then, by using this equation values are projected by 2020 , obtained results are shown in Table 4 .

$$
\mathrm{Y}=3 \mathrm{E}+10 \mathrm{X}+3 \mathrm{E}+11
$$

Table 4. Predicted GDP by 2020

\begin{tabular}{cc}
\hline year & GDP at market prices (current US\$) Norway \\
\hline 2014 & $6.072 \mathrm{E}+13$ \\
2015 & $6.075 \mathrm{E}+13$ \\
2016 & $6.078 \mathrm{E}+13$ \\
2017 & $6.081 \mathrm{E}+13$ \\
2018 & $6.084 \mathrm{E}+13$ \\
2019 & $6.087 \mathrm{E}+13$ \\
2020 & $6.09 \mathrm{E}+13$ \\
\hline
\end{tabular}

The calculated trend line equation of population for the past 10 years by 2013 is shown in equation (3). By utilizing this equation values are projected by 2020 , results obtained are shown in Table 5.

$$
\mathrm{Y}=55874 \mathrm{X}+5 \mathrm{E}+06
$$

Table 5. Projected population by 2020

\begin{tabular}{ll}
\hline year & Population \\
\hline 2014 & 112530236.6 \\
2015 & 112586110.6 \\
2016 & 112641984.6 \\
2017 & 112697858.7 \\
2018 & 112755736.6 \\
2019 & 112811611.6 \\
2020 & 112867486.6 \\
\hline
\end{tabular}

The calculated trend line equation of Industrial growth rate for the past 10 years by 2013 is shown in equation (4). Using this equation values are predicted by 2020 , obtained results are shown in Table 6.

$$
\mathrm{Y}=-0.3479 \mathrm{X}+2.2133
$$

Table 6. Predicted Industrial growth rate by 2020

\begin{tabular}{lc}
\hline year & Industrial growth rate \\
\hline 2014 & -698.4573 \\
2015 & -698.8052 \\
2016 & -699.1531 \\
2017 & -699.501 \\
2018 & -699.8489 \\
2019 & -700.1968 \\
2020 & -700.5447 \\
\hline
\end{tabular}

By having predicted amounts of the three basic economic parameters by 2020 can adopt the best policy to provide country's energy demand until this year.

Finally total consumption by 2020 based on previous results is shown in table 7 :

Table 7. Predicted total consumption by 2020

\begin{tabular}{lc}
\hline year & Total consumption \\
\hline 2014 & $-1.22715 \mathrm{E}+14$ \\
2015 & $-1.22776 \mathrm{E}+14$ \\
2016 & $-1.22836 \mathrm{E}+14$ \\
2017 & $-1.22897 \mathrm{E}+14$ \\
2018 & $-1.22958 \mathrm{E}+14$ \\
2019 & $-1.23018 \mathrm{E}+14$ \\
2020 & $-1.23079 \mathrm{E}+14$ \\
\hline
\end{tabular}

\section{THE FUTURE OF ENERGY IN NORWAY}

EU member states have agreed on the 20-20-20 target by 2020 . So they agreed on a $20 \%$ decline in greenhouse gas (GHG) emissions, $20 \%$ of RE in the energy mix and a $20 \%$ increase in energy efficiency (12. European Commission,2014b. 〈http://ec.europa.eu/energy/efficiency/eed/eed_en. htm〉 (accessed 22.04.14)). The RES directive states the 2020 Target for $20 \% \mathrm{RE}$ sources in the energy consumption mix "increased use of energy from RE sources, together with energy savings and increased energy efficiency, organize measures needed to reduce greenhouse gas emissions and accordance with the Kyoto Protocol (13. European Parliament, 2009. Directive 2009/28/EC of the European Parliament and of the counsil of 23 April 2009 on the promotion of the use of energy from renewable sources and amending and subsequently repealing Directives 2001/ 77/EC and 2003/30/EC, 2009). However, bilateral cooperation among member states can also help the achievement of objectives. Norway is engaged in increasing the share of RE sources $67.5 \%$ by 2020 (Blindheim, 2015) .Norway and Sweden have obligated to an electricity "green" certificate market, which was starting in 2012. Accordingly, this target increases the RE electricity production in Norway and Sweden by a total of 26.4 TWh before 2021, and the consumer's certificate commitment is shared equally (rtifikater, 2011). Table 8 indicates the details of the Norwegian and ${ }_{12}$ 
Swedish RE sources operational programs.

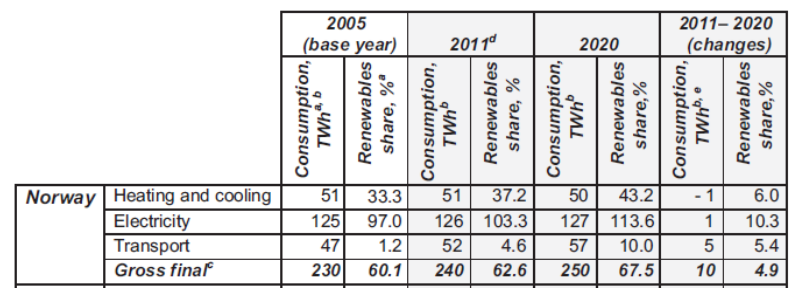

Table 8. Key figures in Norwegian Operational programs for increased RE shares (Direktiv, 2009).

\section{CONCLUSION}

Norway is one of the Nordic countries that is counted an important exporter oil and natural gas to European countries. Nevertheless dependence on imports of fossil resources in any of the parts of the country. This country is also very rich in term of RE sources, particularly hydropower. More than $90 \%$ of its electricity is supplied by this source. In this country energy consumption has a rising trend in the industrial sector therefore, this reason increases the rate of GDP, however, it has a decreasing trend in the residential sector. Since electricity is allocated a large proportion of energy demand in the industrial and residential, as a result the supply of electricity in this country has a vital role. Norway intends to predict energy consumption in future years provides energy demand, as well as by replacing fossil fuels with clean energy optimizes energy system and reduces GHG emissions. In this paper, researchers investigate the status of energy demand in one of the European countries, Norway. First, energy and electricity consumption in various sectors, including industrial, residential, ... are calculated. Then, energy demand in Norway is forecasted by using available tools. After that, the relationship between energy consumption in Norway with Basic economics parameters such as GDP, population and industry growth rate has determined by using linear regression model. Finally, the regression result shows a low correlation between variables. Future studies can investigate other economic, political and technological variables on energy consumption, also take act using other forecasting models in this country.

\section{REFERENCES}

1. H. H. M. R. A. S. Omid Nematollahi, "Energy demands and renewable energy resources in the Middle East," Renewable and Sustainable Energy Reviews, vol. 54, pp. 1172-1181, 2016.

2. R. S. R. A. A. F. J. K. I. W. N. H. Sims, "Mitigation of Climate Change. Contribution of Working Group III to
theFourth Assessment Report of the Intergovernmental Panel on Climate Change," Cambridge University Press, 2007.

3. B. L. Presley K. Wesseh Jr, "Can African countries efficiently build their economies on renewable energy?," Renewable and Sustainable Energy Reviews, vol. 54, pp. 161-173, 2016.

4. M. Irandoust, "The renewable energy-growth nexus with carbon emissions and technological innovation: Evidence from the Nordic countries," Ecological Indicators, vol. 69, pp. 118-125, 2016.

5. "www.norway statistic.com," 2012. [Online].

6. G. B. S. T. a. A. B. Miika Tommila, Energy Policies of IEA Countries Norway 2011 Review, 2010.

7. D. O. M. S. Anne Therese Gullberg, "Towards a low carbon energy future - Renewable energy cooperation," Renewable Energy, vol. 68, pp. 216-222, 2014.

8. L. M. H. Kjersti Aarrestad, fact 2015 energy and water resources in Norway, The Ministry of Petroleum and Energy, 2014.

9. "www.nve.com," [Online].

10. "www.iea.org," [Online].

11. "Energy Balances of OECD Countries, IEA/OECD Paris, 2010, and Energy Balances of non-OECD Countries, IEA/OECD Paris, 2010.C OECD/IEA," 2011. [Online].

12. "www.data.world-bank.org," [Online].

13. "www.indexmundi.com," [Online].

14. "European Commission, 2014b. 〈http://ec.europa.eu/energy/efficiency/eed/eed en. htm〉 (accessed 22.04.14)," [Online].

15. "European Parliament, 2009. Directive 2009/28/EC of the European Parliament and of the counsil of 23 April 2009 on the promotion of the use of energy from renewable sources and amending and subsequently repealing Directives 2001/ 77/EC and 2003/30/EC," 2009. [Online].

16. B. Blindheim, "A missing link? The case of Norway and Sweden: Does increased renewable energy production impact domestic greenhouse gas emissions?," Energy Policy, vol. 77, pp. 207-215, 2015.

17. A. m. k. N. o. k. S. r. o. e. f. m. f. e. rtifikater, "Avtale mellom kongeriket Norges og kongeriket Sveriges regjering om et felles marked for else rtifikater2011.[Agreementonacommongreencertificate market]," 2011.

18. S. N. H. f. f. a. f. e. e. Direktiv, "Government Offices of Sweden[Regeringskanseliet][The Swedish action Plan on Renewable Energy]," 2009. 
